ROZ D Z I A E 13 .

\title{
ZMIANY REGIONALNE W SKUPIE ŻYWCA WIEPRZOWEGO I WOŁOWEGO W POLSCE W LATACH 2000-2017
}

\author{
Anna Olszańska ${ }^{1}$
}

\section{Wstęp}

Wieprzowina i wołowina to podstawowe gatunki mięsa czerwonego produkowanego w Polsce, przy czym rynki te mają zdecydowanie odmienną specyfikę. Wieprzowina jest produkowana przede wszystkim na rynek krajowy. W ogólnej strukturze spożycia mięsa w Polsce, jej konsumpcja jest największa. Wołowina, od wejścia Polski do Unii, jest produkowana głównie na potrzeby eksportu, a jej spożycie na rynku krajowym jest niewielkie i sięgało w ostatnich latach 15\%-20\% produkcji krajowej. Produkcja obu tych rodzajów żywca jest stosunkowo silnie związana z ziemią, chociaż w przypadku trzody chlewnej coraz więcej gospodarstw prowadzących tucz bazuje na paszach z zakupu.

Po wejściu Polski do Unii następowały znaczne zmiany strukturalne w produkcji żywca mięsnego. Głównym, obserwowanym zjawiskiem są procesy koncentracji produkcji wyrażające się zmniejszaniem liczby gospodarstw prowadzących chów zwierząt i wzrostem wielkości stad. Wpływ na to mają stale zawężające się relacje między ceną pasz a cenami skupu żywca. Malejące zyski jednostkowe powodują, że prowadzenie chowu

\footnotetext{
${ }^{1}$ Dr hab. inż. Anna Olszańska, prof. UE, Uniwersytet Ekonomiczny we Wrocławiu.
} 
jest nieopłacalne w przypadku małych stad. Jednocześnie od wielu lat obserwowane są procesy koncentracji w przemyśle mięsnym. Zwiększanie odległości do rynku zbytu jest kolejnym czynnikiem zniechęcającym do prowadzenia produkcji zwierzęcej².

Niewątpliwie wpływ na zmiany strukturalne w chowie trzody, ale także pośrednio i bydła, ma stale rozprzestrzeniający się afrykański pomór świń. Początkowo obejmował on tereny wschodniej Polski, gdzie produkcja trzody jest stosunkowo niewielka. Obecnie sięga terenów centralnej Polski i obejmuje województwa warmińsko-mazurskie, podlaskie, mazowieckie, lubelskie. Choroba wchodzi także w obszar województwa świętokrzyskiego i podkarpackiego. Pojawia się więc realne zagrożenie dla województw wielkopolskiego, łódzkiego i kujawsko-pomorskiego i oznacza bardzo duże problemy dla tego kierunku produkcji ${ }^{3}$.

W tym kontekście celem rozdziału jest wskazanie zmian regionalnych, jakie zachodziły w skupie żywca wieprzowego i wołowego w Polsce w okresie 2000-2017. Zakres czasowy został dobrany celowo, aby obejmował także lata przed przystąpieniem Polski do Unii Europejskiej i zmiany, jakie miały miejsce $\mathrm{w}$ związku $\mathrm{z}$ akcesją. $\mathrm{W}$ opracowaniu wykorzystano dane Głównego Urzędu Statystycznego (GUS) i Instytutu Ekonomiki Rolnictwa i Gospodarki Żywnościowej (IERiGŻ-PIB).

\subsection{Produkcja i skup żywca wieprzowego i wołowego w Polsce w latach 2000-2017}

Rynek żywca wieprzowego jest w Polsce głównym, jeżeli chodzi o konsumpcję, i drugim, pod względem wielkości produkcji, rynkiem mięsnym.

${ }^{2}$ D. Zawadzka, Chów świń w gospodarstwach industrialnych i konwencjonalnych, Referat na konferencję IERiGŻ - PIB nt. Industrial versus small farms - competitors or partners?, Jachranka, grudzień 2018; A. Olszańska, Czynniki kształtujące skup żywca wieprzowego po wejściu Polski do Unii Europejskiej (analiza danych z lat 2000-2015), [w:] Wyzwania na rynku żywca wieprzowego w Polsce, E.J. Szymańska (red.), Wydawnictwo SGGW, Warszawa 2017, s. 35-44.

3 https://bip.wetgiw.gov.pl/asf/mapa [data dostępu: 15.04.2019]. 
Wykres 13.1. Produkcja i skup żywca wieprzowego w Polsce w latach 2000-2017 (tys. ton)

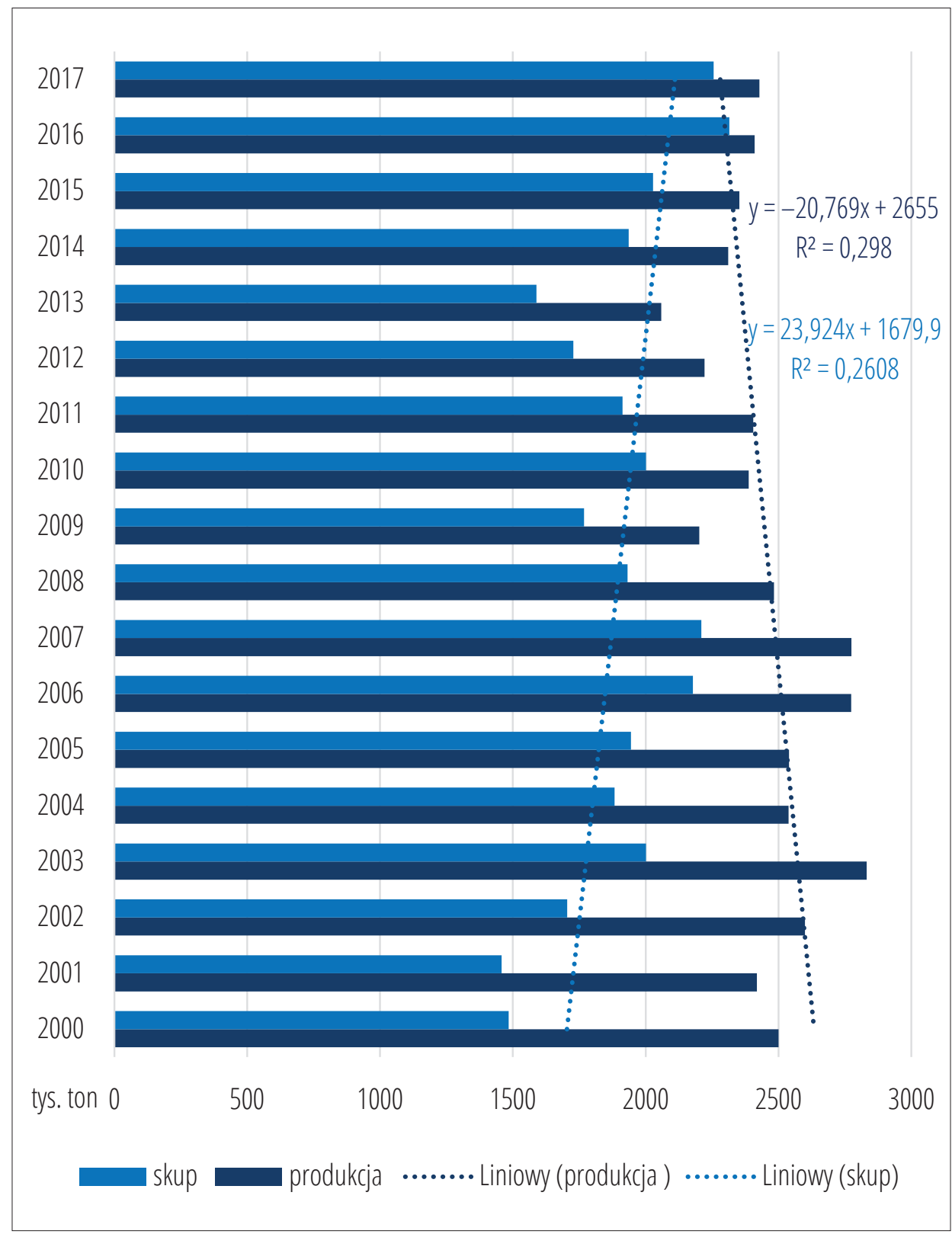

Źródło: opracowanie na podstawie danych: Rynek mięsa stan i perspektywy. Analizy rynkowe, IERiGż-PIB z lat 2001-2018. 
Wielkość produkcji i skupu żywca wieprzowego podlega wahaniom cyklicznym w okresach 3-5-letnich ${ }^{4}$. Produkcja żywca w analizowanym czasie charakteryzuje się tendencją spadkową (przy niskim poziomie dopasowania linii trendu) (wykres 13.1.). W 2017 roku produkcja żywca wieprzowego stanowiła 97\% wielkości produkcji z 2000 roku i 85\% produkcji $\mathrm{z}$ roku 2003, kiedy to odnotowano jej najwyższy poziom w całym analizowanym okresie. Jednocześnie, z uwagi na zmiany cykliczne, w 2017 roku produkcja żywca wieprzowego była o 18\% wyższa niż w 2013 roku, kiedy to odnotowano jej najniższy poziom w ramach tego cyklu, ale także w całym analizowanym okresie osiemnastu lat.

Nieco inny trend obserwuje się w przypadku danych dotyczących wielkości skupu. Przy widocznych i dominujących wahaniach cyklicznych, występuje trend rosnący wielkości skupu. Wynika to z systematycznego i znacznego wzrostu udziału skupu w ogólnej produkcji żywca i marginalizacji pozostałych form jego zagospodarowania. Udział skupu w ogólnej wielkości produkcji wzrósł od 2000 roku z 59\% do 93\% w 2017 roku. W okresie tym rejestrowana wielkość skupu wzrosła o 52\%. Najwyższą wielkość skupu odnotowano w 2016 roku, a najniższą w 2001 roku. Analiza obu trendów wskazuje na znaczne zmiany zachodzące na tym rynku.

Znacznie mniejszą skalą produkcji w omawianych latach charakteryzował się rynek żywca wołowego (wykres 13.2.). W latach 2000-2007 produkcja na tym rynku stanowiła od $29 \%$ do $35 \%$ wielkości produkcji w analogicznym roku na rynku wieprzowiny. Udziały te wyraźnie wzrastały od 2008 roku, osiągając w roku 2017 poziom 48\%. Jest to kierunek produkcji, który wyraźnie się rozwijał w porównaniu do produkcji żywca wieprzowego. W przypadku danych dotyczących wielkości produkcji żywca wołowego odnotowano znaczący trend wzrostowy (przy dobrym dopasowaniu linii trendu). Średnioroczny wzrost wielkości produkcji wynosił

${ }^{4}$ A. Olszańska, Rynek żywca w Polsce (1955-2010) - zmiany strukturalne, koncentracja produkcji, wahania podaży, Wydawnictwo Uniwersytetu Humanistycznego, Wrocław 2012, s. 96. 
28,5 tys. ton. Także na tym rynku występują wahania cykliczne produkcji, przy czym są one dłuższe i powtarzają się co 5-7 lat ${ }^{5}$.

Wykres 13.2. Produkcja i skup żywca wołowego w Polsce w latach 2000-2017 (tys. ton)

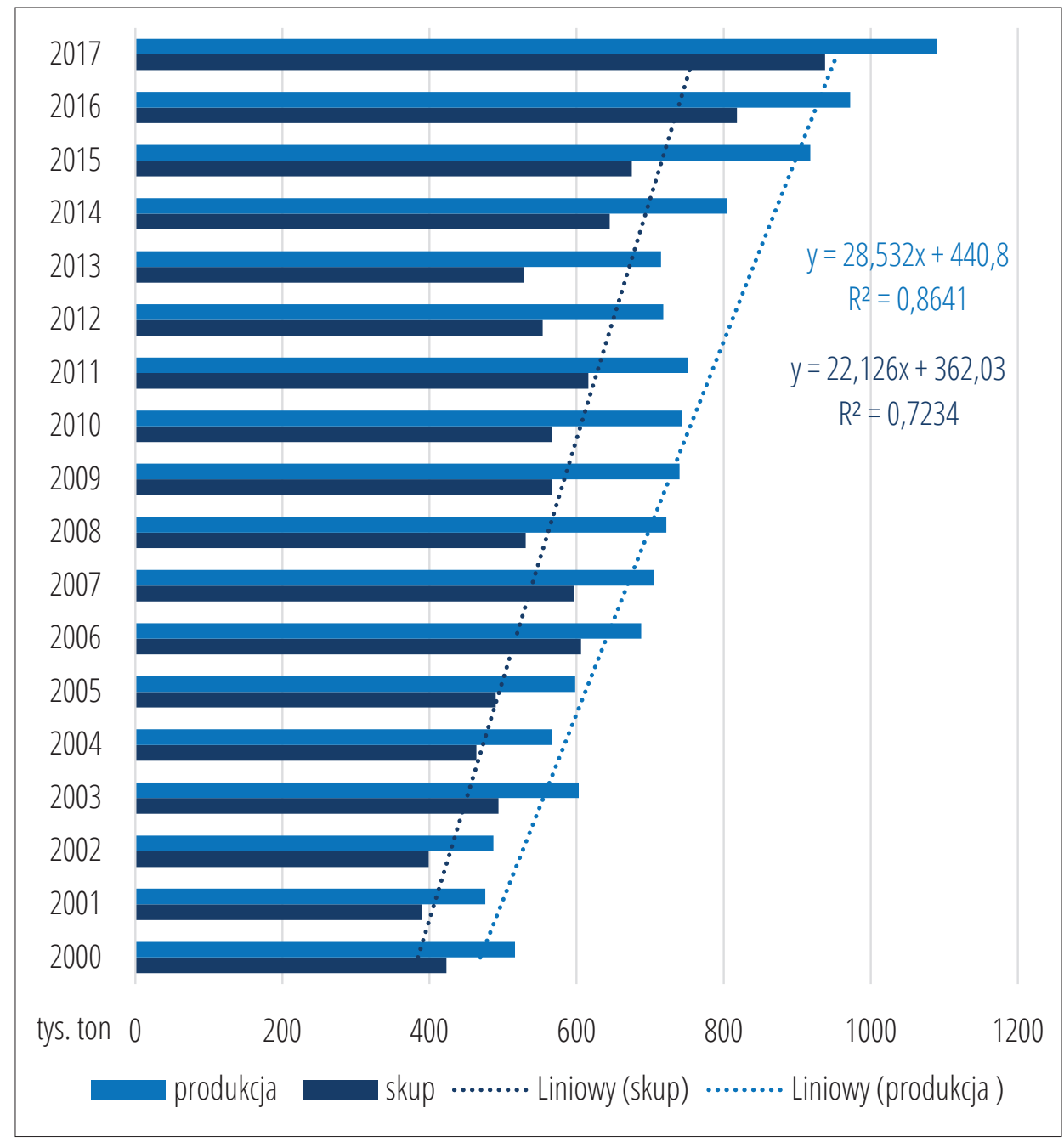

Źródło: opracowanie na podstawie danych: Rynek mięsa: stan i perspektywy. Analizy rynkowe, IERiGż-PIB za lata 2001-2018.

\footnotetext{
5 Tamże, s. 99.
} 
W omawianym okresie 18 lat produkcja żywca wołowego w Polsce wzrosła o $110 \%$.

Analizując dane dotyczące wielkości skupu, także odnotowano trend wzrostowy - o 122\% (średnioroczny wzrost na poziomie 22,1 tys. ton). Udział skupu w wielkości produkcji był zmienny w kolejnych latach i wynosił od 73,5\% w latach 2008 i 2015 do 86,1\% w roku 2017 i 88,1\% w 2006.

Wykres 13.3. Wielkość skupu żywca wieprzowego i wołowego oraz relacja wielkości skupu żywca wołowego w stosunku do żywca wieprzowego w Polsce w latach 2000-2017 (tys. ton)

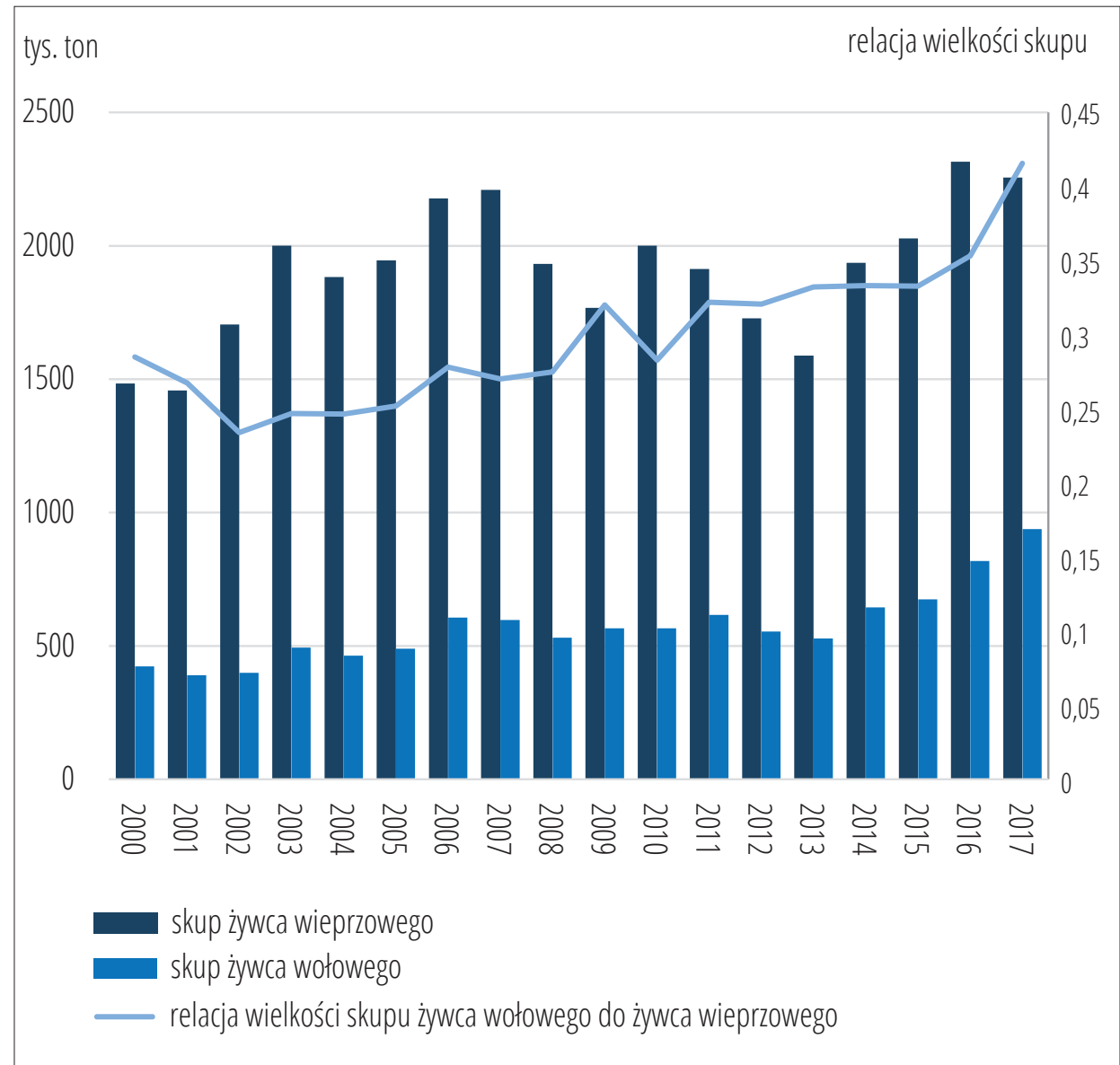

Źródło: opracowanie na podstawie danych: Rynek mięsa: stan i perspektywy. Analizy rynkowe, IERiGŻ-PIB z lata 2001-2018 
Podsumowując analizę danych dotyczących wielkości skupu żywca wieprzowego i wołowego w omawianych latach można stwierdzić, że mimo rosnącej stale produkcji żywca wołowego wielkość jego skupu była znacząco niższa niż skupu żywca wieprzowego (wykres 13.3.). Udział ten jednak stale się zwiększał i osiągnął w 2017 roku poziom 41,6\%, przy średniorocznym tempie wzrostu $0,75 \%$.

\subsection{Zmiany regionalnego zróżnicowania wielkości skupu żywca wieprzowego i wołowego}

Zróżnicowanie wielkości produkcji poszczególnych produktów rolnych między regionami kraju jest zjawiskiem normalnym. Jest ono efektem całego splotu czynników, m.in.: zróżnicowania naturalnych i ekonomicznych warunków prowadzenia produkcji rolnej, warunków otoczenia konkurencyjnego (np. obecność dużej grupy producentów rolnych prowadzących dany kierunek produkcji), otoczenia instytucjonalnego, tradycji, doświadczenia, uwarunkowań historycznych. Producenci grupują się także obecnie wokół dużych, prężnie działających zakładów przetwórczych, zwłaszcza tych, które rozwijają więzi integracyjne z dostawcami surowca i aktywnie tworzą własną bazę surowcową. Odległość do rynku zbytu i koszty z tym związane w istotny sposób wpływają na ceny skupu, a zatem opłacalność prowadzonej produkcji. Znaczący wpływ mają także uwarunkowania związane z globalizacją gospodarki oraz uwarunkowania prawne (np. regulacje w zakresie zrównoważonego rozwoju i ochrony środowiska naturalnego, a także zasady WPR) ${ }^{6}$.

Aby uzyskać możliwość porównań w czasie danych dotyczących poszczególnych województw (przy zmieniającym się średnim poziomie

${ }^{6}$ S. Okularczyk, Wpływ mechanizmów rynku na koncentracje i poziom produkcji świń, „Trzoda Chlewna” 1999, nr 20, s. 8-12; A. Witczak, Analysis of Regional Differentiation of Hog Livestock Production in Poland in 2004, "Electronic Journal of Polish Agricultural Universities" 2006, t. 9, nr 2, www.ejpau.media.pl/economics/ volume9/issue2/index_stitle_sabs.html [data dostępu: 06.04.2019]. 
wielkości przyjętych danych), jako miarę zróżnicowania analizowanych wielkości przyjęto odchylenie standardowe (S(x)) w stosunku do wartości średniej $(\bar{x})$. Posługując się tą miarą można wyodrębnić grupy województw, które różnią się poziomem wielkości danej cechy w stosunku do wielkości średnich $\mathrm{w}$ danym roku ${ }^{7}$.

1) Województwa charakteryzujące się poziomem danej cechy powyżej średniej zaliczono do następujących grup:

- grupa $1-<\bar{x}, \bar{x}+1 * S(x))$,

- grupa $2-<\bar{x}+1 * \mathrm{~S}(\mathrm{x}), \bar{x}+2 * \mathrm{~S}(\mathrm{x}))$,

- grupa $3-<\bar{x}+2 * S(x), \bar{x}+3 * S(x))$ i dalsze w miarę potrzeb.

2) Województwa charakteryzujące się poziomem danej cechy poniżej średniej:

- grupa $-1-(\bar{x}, \bar{x}-1 * \mathrm{~S}(\mathrm{x})>$,

- grupa $-2-(\bar{x}-1 * S(x), \bar{x}-2 * S(x)>$ i dalsze.

Liczba wyodrębnionych grup jest zmienna i zależy od zróżnicowania badanych wielkości w danym roku. Zaletą takiego sposobu analizy danych jest łatwa możliwość porównań zmian w rozkładzie regionalnym danych wartości w czasie. Niestety jednocześnie traci się perspektywę oceny bezwzględnych zmian wartości danych pomiędzy poszczególnymi latami, z czego wynika konieczność dodatkowych analiz danych pierwotnych.

W tabeli 13.1. przedstawiono zmiany w wielkości skupu trzody chlewnej w Polsce w latach 2000-2017. Analiza dotyczy wielkości skupu żywca wieprzowego w przeliczeniu na 1 hektar użytków rolnych. Bardzo duże zróżnicowanie województw powoduje, że wartość odchylenia standardowego jest w tym przypadku bardzo wysoka. W związku z tym występowała też niewielka liczba grup, którą wyodrębniano w kolejnych latach.

7 A. Olszańska, Rynek żywca w Polsce (1955-2010)..., s. 99. 
Tabela 13.1. Zróżnicowanie wielkości skupu żywca wieprzowego w Polsce w latach 2000-2017 (dane pierwotne $w \mathrm{~kg} / \mathrm{ha}$ UR)

Województwo

\begin{tabular}{|c|c|c|c|c|c|c|c|c|c|c|c|c|c|c|c|c|c|c|}
\hline wielkopolskie & 3 & 3 & 3 & 3 & 3 & 3 & 3 & 3 & 3 & 3 & 3 & 3 & 3 & 2 & 2 & 3 & 2 & 2 \\
\hline pomorskie & -1 & -1 & -1 & -1 & -1 & -1 & -1 & 1 & 1 & 1 & 1 & 2 & 2 & 2 & 2 & 2 & 2 & 2 \\
\hline tódzkie & 1 & 2 & 2 & 1 & 1 & 1 & 2 & 2 & 2 & 1 & 1 & 2 & 1 & 1 & 2 & 2 & 2 & 2 \\
\hline $\begin{array}{l}\text { kujawsko- } \\
\text {-pomorskie }\end{array}$ & 2 & 2 & 2 & 2 & 2 & 2 & 2 & 2 & 1 & 2 & 2 & 2 & 2 & 2 & 2 & 1 & 2 & 1 \\
\hline opolskie & -1 & -1 & -1 & -1 & -1 & -1 & -1 & -1 & -1 & -1 & 1 & 1 & 1 & -1 & -1 & -1 & -1 & -1 \\
\hline śląskie & -1 & -1 & -1 & -1 & 1 & 1 & -1 & 1 & 1 & 1 & -1 & -1 & -1 & -1 & -1 & -1 & -1 & -1 \\
\hline małopolskie & -1 & -1 & -1 & -1 & -1 & -1 & -1 & -1 & -1 & -1 & -1 & -1 & -1 & -1 & -1 & -1 & -1 & -1 \\
\hline mazowieckie & -1 & -1 & -1 & -1 & -1 & -1 & -1 & -1 & -1 & -1 & -1 & -1 & -1 & -1 & -1 & -1 & -1 & -1 \\
\hline podlaskie & -1 & -1 & -1 & -1 & -1 & -1 & -1 & -1 & -1 & -1 & -1 & -1 & -1 & -1 & -1 & -1 & -1 & -1 \\
\hline lubelskie & -1 & -1 & -1 & -1 & -1 & -1 & -1 & -1 & -1 & -1 & -1 & -1 & -1 & -1 & -1 & -1 & -1 & -1 \\
\hline świętokrzyskie & -2 & -1 & -1 & -1 & -1 & -1 & -1 & -1 & -1 & -1 & -1 & -1 & -1 & -1 & -1 & -1 & -1 & -1 \\
\hline $\begin{array}{l}\text { warmińsko- } \\
\text {-mazurskie }\end{array}$ & -1 & -1 & -1 & -1 & -1 & -1 & -1 & -1 & -1 & -1 & -1 & -1 & -1 & -1 & -1 & -1 & -1 & -1 \\
\hline $\begin{array}{l}\text { zachodnio- } \\
\text { pomorskie }\end{array}$ & -1 & -1 & -1 & -1 & -1 & -1 & -1 & -1 & -1 & -1 & -1 & -1 & -1 & -1 & -1 & -1 & -1 & -1 \\
\hline lubuskie & -1 & -1 & -1 & -1 & -1 & -1 & -1 & -1 & -1 & -1 & -1 & -1 & -2 & -1 & -1 & -1 & -1 & -1 \\
\hline podkarpackie & -1 & -1 & -1 & -1 & -1 & -1 & -2 & -1 & -1 & -1 & -2 & -2 & -2 & -2 & -1 & -1 & -1 & -1 \\
\hline dolnośląskie & -1 & -2 & -2 & -2 & -1 & -2 & -2 & -2 & -2 & -2 & -2 & -2 & -2 & -2 & -2 & -2 & -2 & -2 \\
\hline
\end{tabular}

Źródło: opracowanie na podstawie danych: Skup i ceny produktów rolnych, lata 2001-2018, GUS, https://stat.gov.pl/publikacje/publikacje [data dostępu: 10.04. 2019].

Na podstawie tych analiz można stwierdzić, że zróżnicowanie skupu między województwami było w analizowanych latach bardzo duże 
(tabela 13.1.). Wyodrębniła się nieliczna grupa województw, w których produkcja prowadzona była na bardzo dużą skalę. W pozostałych województwach wielkość skupu kształtowała się poniżej średniej w danym roku.

W województwie dolnośląskim odnotowywany był najmniejszy w skali kraju skup wieprzowiny. W większości analizowanych lat było to jedyne województwo, w którym skup odnotowywano w skali sytuującej się w drugiej grupie poniżej średniej. Co więcej, udział tego województwa w ogólnej wielkości skupu w kraju systematycznie malał w kolejnych latach, co oznacza wycofywanie się rolników z produkcji trzody na tym obszarze. Proces ten zdynamizował się po wejściu Polski do Unii Europejskiej. W latach 2000-2005 udział ten wynosił od 2,5\% w roku 2000 do 2,8\% w roku 2004. W kolejnych latach wielkości skupu w tym województwie malały i w roku 2017 osiągnęły 0,36\% ogólnej wielkości skupu żywca wieprzowego w kraju. W tym roku skup żywca wieprzowego w województwie dolnośląskim stanowił 22\% wielkości skupu z roku 2000.

Do grupy -1, czyli skupu mieszczącego się w przedziale od średniej do średniej minus jedno odchylenie standardowe, należało w większości analizowanych lat jedenaście województw. Uwzględniając bezwzględną wielkość skupu należy jednak stwierdzić, że grupa ta była bardzo zróżnicowana. Jednakże udział województw, w których odnotowywany był skup poniżej średniej rocznej dla kraju, stopniowo malał. W 2000 roku wynosił 47,3\% skupu żywca wieprzowego w kraju i do 2017 roku zmalał do 39,9\%.

Największym skupem w przeliczeniu na hektar użytków rolnych legitymizuje się województwo wielkopolskie. Jest ono absolutnym liderem w kraju zarówno w przypadku wielkości skupu, jak i w przeliczeniu na jednostkę powierzchni UR. W 2000 roku wynosiła ona $239 \mathrm{~kg} / \mathrm{ha}$ UR i do 2017 roku wzrosła do $341 \mathrm{~kg} /$ ha użytków rolnych (UR), przy czym maksymalną, jak do tej pory, wielkość odnotowano w 2016 roku i wynosiła ona $361 \mathrm{~kg} /$ ha UR. W 2000 roku skupiono w tym województwie 453 tys. ton żywca wieprzowego, co stanowiło 30,5\% ogólnej ilości żywca wieprzowego skupionego w tym roku w Polsce. Wielkość ta wzrosła do 2017 roku do 609,9 tys. ton, co stanowiło tylko 27\% ogólnej wielkości w kraju. W analizowanym okresie wielkość skupu w tym województwie wzrastała 
wolniej niż dla całego kraju i dla wielu innych województw. Wzrost ten w województwie wielkopolskim wyniósł 34,7\% (w Polsce 52\%). Jest to dość przewidywalne zjawisko przy tak wysokim poziomie produkcji.

Do grupy wyróżniających się regionów należą także województwa łódzkie i pomorskie. W ostatnim $\mathrm{z}$ analizowanych lat osiągnęły one podobne wielkości skupu żywca wieprzowego wynoszące nieco ponad 12\% ogólnej wielkości skupu w kraju, przy czym w 2017 roku wielkość skupu w województwie pomorskim w przeliczeniu na 1 ha UR była znacząco wyższa niż w województwie wielkopolskim i wynosiła $365 \mathrm{~kg} / \mathrm{ha}$ UR. W województwie łódzkim była około 90 kg mniejsza i wynosiła $273 \mathrm{~kg}$ / ha UR. W województwie pomorskim w analizowanych latach nastąpił prawie pięciokrotny wzrost wielkości skupu (495\%). Dane wskazują, że był to region, gdzie chów trzody chlewnej rozwinął się w analizowanych latach najbardziej. W województwie łódzkim skup wzrósł o 117\%. Czwartym województwem w czołówce jest kujawsko-pomorskie. Tam jednak odnotowano bardzo niską dynamikę wzrostu wielkości skupu - zaledwie 19\%. Stąd jego pozycja w rankingu województw systematycznie spadała.

W Polsce występowały także województwa niewyróżniające się wielkością skupu, gdzie odnotowano wyższą niż w kraju dynamikę wzrostu jego wielkości: świętokrzyskie (wzrost o 271\%), opolskie (wzrost o 120\%) oraz mazowieckie i warmińsko-mazurskie (wzrost o 62\%). W analizowanym okresie udział czterech wymienianych wcześniej województw w ogólnej wielkości skupu wynosił od 52,7\% w roku 2000 do 61,9\% w roku 2017.

W tabeli 13.2. przedstawiono zróżnicowanie wielkości skupu żywca wołowego w przeliczeniu na 1 ha UR w analizowanych latach. W tym przypadku nie jest obserwowana tak silna polaryzacja, jak w skupie żywca wieprzowego. Odnotowano około 8 województw, gdzie wielkość skupu w przeliczeniu na jednostkę powierzchni kształtowała się powyżej wartości średniej skupu dla Polski, sporadycznie tylko występowały podziały na 5 grup województw, poszczególne województwa relatywnie częściej zmieniały swoją pozycję w stosunku do pozostałych, niższe były także wielkości odchyleń standardowych w stosunku do średniej wielkości skupu w danym 
roku. Generalnie można stwierdzić, że poziom zróżnicowania województw w przypadku wielkości skupu żywca wołowego był znacznie mniejszy.

Tabela 13.2. Zróżnicowanie wielkości skupu żywca wołowego w Polsce w latach 2000-2017 (dane pierwotne w kg/ha UR)

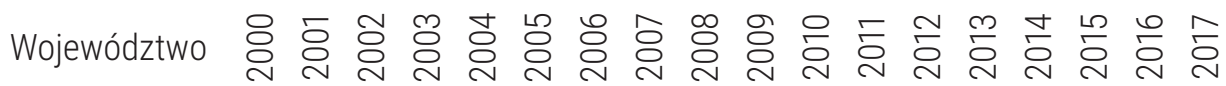

\begin{tabular}{lllllllllllllllllllll}
\hline \hline łódzkie & 1 & 2 & 2 & 2 & 2 & 2 & 2 & 2 & 2 & 2 & 1 & 2 & 2 & 2 & 2 & 2 & 2 & 1 \\
\hline wielkopolskie & 2 & 3 & 2 & 3 & 2 & 2 & 2 & 2 & 2 & 2 & 2 & 2 & 2 & 2 & 2 & 2 & 2 & 2 \\
\hline małopolskie & 2 & 2 & 1 & 2 & 1 & 1 & 2 & 2 & 1 & 3 & 2 & 2 & 1 & 1 & 1 & 1 & -1 & 1 \\
\hline śląskie & 1 & 1 & -1 & -1 & 1 & 1 & 1 & 1 & 1 & 2 & 1 & 1 & 1 & 1 & 1 & 1 & 1 & -1 \\
\hline mazowieckie & -1 & 1 & -1 & 1 & 1 & 1 & 1 & 1 & 1 & 1 & 1 & 1 & 1 & 1 & 1 & 1 & 1 & 1 \\
\hline podlaskie & 1 & 1 & 1 & 1 & 1 & 1 & 1 & 1 & 1 & 1 & 2 & 2 & 1 & 1 & 2 & 1 & 1 & 1 \\
\hline kujawsko- & 1 & 1 & 1 & -1 & 1 & 1 & 1 & 1 & -1 & -1 & -1 & -1 & -1 & 1 & 1 & 1 & 1 & 1 \\
-pomorskie & 1 & & & & & & & & & & & & & & & & & \\
\hline świętokrzyskie & -1 & -1 & -1 & -1 & -1 & -1 & -1 & -1 & -1 & 1 & 1 & 1 & 1 & -1 & 1 & 1 & 1 & 1 \\
\hline lubelskie & -1 & -1 & -1 & -1 & -1 & -1 & -1 & -1 & -1 & -1 & -1 & -1 & -1 & -1 & -1 & -1 & -1 & -1 \\
\hline opolskie & -1 & -1 & -1 & -1 & -1 & -2 & -1 & -1 & -1 & -1 & -1 & -1 & -1 & -1 & -2 & -2 & -2 & -2 \\
\hline warmińsko- & 1 & 1 & 1 & -1 & -1 & -1 & -1 & -1 & -1 & -1 & -1 & -2 & -2 & -1 & -1 & -1 & -1 & -1 \\
-mazurskie & 1 & & & & & & & & & & & & & & & & & \\
\hline pomorskie & -2 & -2 & -2 & -2 & -2 & -2 & -2 & -2 & -2 & -1 & -1 & -1 & -1 & -1 & -1 & -1 & -1 & -1 \\
\hline dolnośląskie & -2 & -2 & -2 & -2 & -2 & -2 & -2 & -2 & -2 & -1 & -2 & -2 & -2 & -2 & -2 & -2 & -2 & -2 \\
\hline podkarpackie & 1 & -1 & -1 & -1 & -1 & -1 & -1 & -1 & -1 & -1 & -2 & -2 & -2 & -2 & -2 & -2 & -2 & -2 \\
\hline lubuskie & -2 & -1 & -1 & -2 & -2 & -2 & -2 & -2 & -2 & -2 & -2 & -2 & -2 & -2 & -2 & -2 & -2 & -2 \\
\hline zachodnio- & -2 & -2 & -2 & -2 & -2 & -2 & -1 & -2 & -2 & -2 & -2 & -2 & -2 & -2 & -2 & -2 & -2 & -2 \\
pomorskie & & & & & & & & & & & & & & & & & & \\
\hline
\end{tabular}

Źródło: opracowanie na podstawie danych: Skup i ceny produktów rolnych, lata 2001-2018, GUS, https://stat.gov.pl/publikacje/publikacje [data dostępu: 10.04. 2019]. 
W większości analizowanych lat poniżej średniej w kraju skupowano żywiec wołowy w województwach: dolnośląskim, podkarpackim, lubuskim i zachodniopomorskim. Do wyróżniających się w całym analizowanym okresie należały województwa wielkopolskie i łódzkie. Wyższy od średniej skup w początkowych latach analizy występował także w województwie małopolskim.

Skup w Polsce w przeliczeniu na jednostkę powierzchni wzrósł w analizowanych latach o 167\%. Zdecydowanie wyróżniały się pod tym względem województwa świętokrzyskie (wzrost o 456\%) i mazowieckie (wzrost o 375\%). Powyżej średniej dla kraju wzrósł także skup w województwach kujawsko-pomorskim, łódzkim, podlaskim i pomorskim. Odnotowano też województwa, gdzie wielkość skupu w przeliczeniu na 1 hektar UR w 2017 roku w porównaniu do 2000 roku zmniejszyła się. Należały do nich podkarpackie (56\%) i zachodniopomorskie (69\%). W województwie wielkopolskim skup żywca wołowego rósł w podobnym tempie jak średnio w kraju.

Udział województwa wielkopolskiego w ogólnej wielkości skupu żywca wołowego wzrósł w analizowanym okresie z 18,7\% do 21,8\%. Łączny udział województw małopolskiego, łódzkiego i wielkopolskiego w ogólnej wielkości skupu żywca wołowego wzrósł w analizowanych latach nieznacznie (z 34,3\% do 35,8\%). Mimo mniejszego zróżnicowania wielkości skupu żywca wołowego niż żywca wieprzowego, udział województwa wielkopolskiego był znaczący, ale już trzech pierwszych był mniejszy niż w przypadku żywca wieprzowego. Można także wskazać aż pięć województw, gdzie skup był na bardzo niskim poziomie: lubuskie $(0,6 \%)$, zachodniopomorskie $(0,8 \%)$, podkarpackie $(0,9 \%)$, opolskie $(1,2 \%)$, dolnośląskie $(1,7 \%)$.

\section{Podsumowanie}

Skup żywca wieprzowego i wołowego w analizowanych latach zwiększył się, co należy wiązać z wejściem Polski do Unii Europejskiej i rozwojem możliwości eksportu mięsa i przetworów. W analizowanym okresie nie wzrósł bowiem znacząco rynek wewnętrzny mięsa i przetworów. Skup 
żywca wołowego rozwijał się znacznie szybciej niż żywca wieprzowego mimo znacznego spadku spożycia tego mięsa na rynku wewnętrznym.

W skupie żywca wieprzowego wyodrębniła się grupa czterech województw, w których stale obserwowany był skup żywca powyżej średniej krajowej. W dalszych jedenastu województwach, na różnym poziomie, skup kształtował się poniżej średniej. W województwie dolnośląskim chów i skup trzody stopniowo zanikał.

W przypadku żywca wołowego zróżnicowanie województw nie było tak utrwalone i poszczególne województwa stosunkowo często zmieniały swoją pozycję w stosunku do pozostałych. Względnie stała grupa trzech liderów o największej skali skupu posiadała jednak znacznie mniejsze udziały w rynku żywca wołowego niż grupa czterech województw o największym skupie na rynku żywca wieprzowego.

Na obu rynkach zdecydowanie wyróżniało się w skupie województwo wielkopolskie. Świadczy to o bardzo wysokim poziomie koncentracji produkcji zwierzęcej i niewątpliwie ma to swoje negatywne konsekwencje dla stanu środowiska naturalnego. Niski poziom skupu na obu rynkach występował w województwie dolnośląskim. 